\title{
Penerapan Pendekatan STML dengan Strategi Siklus Belajar Empiris-Induktif untuk Meningkatkan Hasil Belajar dan Literasi Sains-Teknologi Siswa
}

\author{
${ }^{1 *}$ Muhali, ${ }^{2}$ Muhammad Asy'ari \\ ${ }^{1}$ Program Studi Pendidikan Kimia, FSTT, Universitas Pendidikan Mandalika, Jl. Pemuda No. \\ 59A Mataram, Indonesia 83125 \\ ${ }^{2}$ Program Studi Pendidikan Olahraga dan Kesehatan, FIKKM, Universitas Pendidikan \\ Mandalika, Jl. Pemuda No. 59A Mataram, Indonesia 83125 \\ ^Email Korespondensi: muhali@ikipmataram.ac.id
}

\begin{abstract}
Abstrak
Penelitian ini bertujuan untuk (1) meningkatkan hasil belajar siswa, (2) meningkatkan literasi sains teknologi (LST) siswa, dan (3) mendeskripsikan respon siswa terhadap penerapan pendekatan Sains Teknologi Masyarakat dan Lingkungan (STML) dengan strategi siklus belajar empiris-induktif dalam pembelajaran fisika pada materi rangkaian listrik dan hukum Ohm. Penelitian ini merupakan penelitian tindakan kelas, yang dilaksanakan dalam 2 (dua) siklus. Subyek penelitian ini adalah siswa kelas X MAN 3 Lombok Tengah tahun pelajaran 2020/2021 yang berjumlah 45 siswa. Instrument penelitian yang digunakan dalam penelitian ini berupa tes hasil belajar, tes literasi sains dan teknologi, dan angket respon. Data penelitian dianalisis secara deskriptif kuntitatif. Hasil penelitian menunjukkan bahwa penerapan pendekatan STML dengan strategi siklus belajar empiris-induktif dapat meningkatkan (1) hasil belajar, (2) LST dan (3) respon posistif siswa berdasarkan tinjauan peningkataan siklus I dan siklus II. Berdasarkan hasil penelitian, dapat disimpulkan bahwa pendekatan STML dengan strategi siklus belajar empiris-induktif dapat meningkatkan hasil belajar, LST, dan respon positif siswa dalam pembelajaran fisika pada materi rangkaian listrik dan hukum Ohm.
\end{abstract}

Kata kunci: STML; siklus belajar; empiris-induktif, hasil belajar, literasi sains teknologi; respon siswa

\section{Application of STML Approach with Empirical-Inductive Learning Cycle Strategy to Improve Student's Learning Outcomes and Science-Technology Literacy}

\begin{abstract}
This study aimed to (1) improve student learning outcomes, (2) improve students' science technology literacy (LST), and (3) describe student responses to the application of the Community and Environmental Science Technology (STML) approach with an empirical-inductive learning cycle strategy in learning physics on electrical circuit material and Ohm's law. This research is a classroom action research, which is carried out in 2 (two) cycles. The subjects of this study were students of class X MAN 3 Central Lombok in the academic year 2020/2021, totaling 45 students. The research instruments used in this study were learning outcomes tests, scientific and technological literacy tests, and response questionnaires. The research data were analyzed descriptively and quantitatively. The results showed that the application of the STML approach with an empiricalinductive learning cycle strategy could improve (1) learning outcomes, (2) LST and (3) students' positive responses based on a review of the improvement in cycle I and cycle II. Based on the results of the study, it can be concluded that the STML approach with the empirical-inductive learning cycle strategy can improve student learning outcomes, LST, and positive responses of students in learning physics on electrical circuits and Ohm's law material.
\end{abstract}

Keywords: STML; learning cycle; empirical-inductive, learning outcomes, science-technology literacy; student response

How to Cite: Muhali, M., \& Asy'ari, M. (2021). Penerapan Pendekatan STML dengan Strategi Siklus Belajar Empiris-Induktif untuk Meningkatkan Hasil Belajar dan Literasi Sains-Teknologi Siswa. Empiricism Journal, 2(1), 1-9. https://doi.org/10.36312/ej.v2i1.473 


\section{PENDAHULUAN}

Literasi sains sangat penting bagi siswa (Abdullah, 2019), yang dalam beberapa tahun terakhir seringkali dikaitkan bahkan diintegrasikan dengan teknologi (Khoiriah \& Kholiq, 2019). Pada konteks pembelajaran sains, teknologi diklaim memiliki hubungan erat yang bahkan tidak dapat dipisahkan dari kehidupan manusia, baik secara individu maupun sebagai warga masyarakat (Kemendikbud, 2017). Sayangnya, masalah kualitas pendidikan sampai saat ini masih menjadi isu yang menarik dibicarakan pada dunia pendidikan (Sukaisih \& Muhali, 2014), termasuk kemampuan guru yang dinyatakan perlu ditingkatkan secara terus-menerus untuk menguasai dan mengembangkan ilmu pengetahuan dan teknologi (Ardianto \& Rubini, 2016; Laugksch, 2000; Pahrudin et al., 2019).

Topic diskusi dan penelitian terkait literasi sains mulai berkembang dan mendapatkan perhatian lebih dalam bidang akademik pada beberapa tahun terakhir di Indonesia (Nurhasanah et al., 2020). Tak mengherankan, literasi sains disinyalir sebgai dasar dalam pemecahan masalah akademik maupun interaksi real dalam lingkungan masyarakat (Chusni et al., 2018) yang dinyatakan dapat dijadikan indicator kesiapan siswa menghadapi perkembangan teknologi yang makin pesan di masa revolusi industry 4.0 (Fathurrohman \& Astuti, 2017). Identifikasi masalah dan penarikan kesimpulan berdasarkan bukti saintifik merupakan komponen-komponen penting dalam literasi sains yang harus dimiliki siswa untuk memahami serta membuat keputusan tentang alam dan perubahan yang dilakukan terhadap alam melalui aktivitas manusia (Pratiwi et al., 2019). Meski-begitu, permasalahan terkait rendahnya literasi sain-teknologi siswa (OCED, 2016) perlu mendapatkan perhatian khusus karena secara empiris dinyatakan berkorelasi secara langsung dalam pembentukan pemikiran dan sikap ilmiah yang kuat pada generasi baru (Linder et al., 2014).

Beberapa permasalahan yang dialami oleh peneliti yang pada konteks ini merupakan guru pada mata pelajaran fisika di MAN 3 Lombok Tengah yaitu (1) hasil belajar pada mata pelajaran fisika masih rendah, (2) aktivitas siswa dalam pembelajaran belum optimal, (3) guru masih mendominasi proses pembelajaran sehingga keterlibatan siswa dalam proses pembelajaran yang masih kurang aktif, termasuk dalam literasi sains siswa, (4) materi yang disajikan jarang dikaitkan dengan isu-isu sosial dan teknologi yang berkembang di masyarakat, sehingga belum terbiasa untuk memecahkan masalah-masalah yang ada dalam lingkup kehidupan siswa, dan (5) sebagian besar siswa kurang tertarik dalam mengikuti pelajaran fisika karena anggapan fisika sebagai pelajaran yang sulit.

Pengalaman peneliti dalam melaksanakan pembelajaran mengindikasikan beberapa hal yang menarik perhatian dan perlu mendapatkan penanganan yang serius. Pembelajaran sains khususnya fisika, pada dasarnya siswa dituntut untuk memiliki kesadaran dan kemampuan menyelesaikan masalah, menggunakan konsep-konsep sains, mengenal teknologi beserta dampaknya, maupun menggunakan produk teknologi dan memeliharanya, kreatif membuat hasil teknologi yang sederhana dan mampu mengambil keputusan. Pemanfaatan sains dan teknologi demi keselamatan umat manusia, mampu memilah dan memilih teknologi yang ramah akan lingkungan, dapat mengantisipasi dan mengeliminir dampak-dampak negatif dari perkembangan sains dan teknologi, dan dapat menggunakan konsep-konsep dan prinsip-prinsip sains guna memecahkan masalah dalam berbagai aspek kehidupan sehari-hari, maka sangat dibutuhkan warga masyarakat yang literasi sains dan teknologi.

Berbagai permasalahan yang dialami pada lokasi penelitian berdasarkan hasil observasi peneliti yang juga selaku guru pada mata pelajaran fisika di MAN 3 Lombok Tengah: (1) hasil belajar pada mata pelajaran fisika masih rendah pada sebagian besar siswa, (2) aktivitas siswa dalam pembelajaran belum optimal, dilihat dari keantusiasan siswa dalam mengikuti pembelajaran masih rendah, (3) guru masih mendominasi proses pembelajaran sehingga keterlibatan siswa dalam proses pembelajaran yang masih kurang aktif, termasuk dalam literasi sains siswa, (4) materi yang disajikan jarang dikaitkan dengan isu-isu sosial dan teknologi yang berkembang di masyarakat, sehingga belum terbiasa untuk memecahkan masalah-masalah yang ada dalam lingkup kehidupan siswa, dan (5) sebagian besar siswa kurang tertarik dalam mengikuti pelajaran fisika dengan anggapan fisika sebagai pelajaran yang sulit, banyak rumus dan perhitungannya.

Selain itu, hasil observasi mengindikasikan beberapa hal yang menarik perhatian dan perlu mendapatkan penanganan yang serius. Pembelajaran sains khususnya fisika, pada 
dasarnya menuntut siswa untuk memiliki kesadaran dan kemampuan menyelesaikan masalah, menggunakan konsep-konsep sains, mengenal teknologi dan dampak penggunaan, pemeliharaan, kreatif membuat hasil teknologi yang sederhana dan mampu mengambil keputusan dalam penggunaan teknologi.

Beberapa penelitian terkait penelitian literasi sains telah dilakukan di Indonesia (Ni'mah, 2019). Hasil penelitian menunjukkan bahwa literasi sains siswa sekolah menengah berada pada kategori rendah (Kurniawati et al., 2019; Pamungkas et al., 2018; Parno et al., 2018), sehingga penerapan pendekatan pembelajaran yang relevan penting dilakukan, sehingga hasil belajar dan literasi sains-teknologi siswa diharapkan dapat ditingkatkan secara optimal. Tindakan yang dilakukan dalam penelitian ini adalah dengan menerapkan pendekatan STML dengan siklus belajar empiris-induktif yang diharapkan dapat meningkatkan hasil belajar dan literasi sains-teknologi siswa pada mata pelajaran Fisika khususnya di MAN 3 Lombok Tengah. Penelitian tentang penerapan pendekatan STML telah dilakukan oleh peneliti, walaupun dalam implementasinya pendekatan ini dapat memberikan peningkatan terhadap aktivitas dan hasil belajar siswa, namun peningkatan tersebut belum maksimal (Sukaisih, 2013).

Pendekatan STML merupakan pendekatan yang menggabungkan sains, teknologi dan masyarakat (STM) dengan ilmu lingkungan. Pendekatan STML sangat memperhatikan isuisu sosial yang ada di masyarakat dan juga isu-isu lingkungan yang dipengaruhi oleh perkembangan sains dan teknologi. Pendekatan STML memberikan informasi kepada pebelajar tentang apa yang bisa disediakan lingkungan terhadap sains, teknologi dan masyarakat untuk memperoleh keuntungan dari keberadaannya. Hal ini memungkinkan siswa akan memahami bagaimana teknologi mempengaruhi perkembangan sains, mempengaruhi lingkungan dan masyarakat pada waktu yang bersamaan. Penekanannya harus pada bagaimana untuk memungkinkan siswa dalam mendalami pengetahuan dengan hubungan timbal balik secara penuh antara sains, teknologi, masyarakat dan lingkungan. Siswa diberikan kesempatan untuk meramal pengetahuan yang telah diperoleh dari pendidikan, sehingga memecahkan masalah-masalah baru baik yang terprediksi maupun yang tidak terprediksi (Rideng, 2000). Pengajaran sains di sekolah dengan pendekatan STML, mendorong siswa untuk menerapkan ilmu yang dipelajari untuk kehidupan keseharian mereka dan juga dalam memecahkan masalah-masalah dalam kehidupan bermasyarakat. Pendekatan STML ini cocok untuk diterapkan khususnya pada pembelajaran fisika karena dengan pendekatan ini siswa dapat memecahkan masalahmasalah yang berhubungan dengan kemajuan sains dan teknologi serta kebutuhan masyarakat dan lingkungan (Sukaisih, 2004).

Adapun langkah-langkah pembelajaran dengan pendekatan STML yang menggunakan siklus belajar empiris induktif adalah (1) fase eksplorasi, dalam fase ini siswa diminta untuk mengemukakan isu-isu sosial yang mereka alami atau yang pernah mereka lihat dalam kehidupan sehari-hari, kemudian siswa belajar melalui aksi-reaksi mereka sendiri (melalui percobaan/eksperimen) dan mengerjakan kegiatan-kegiatan yang tertera dalam LKS; (2) fase pengenalan konsep, pada fase ini guru sebagai fasilitator/mediator mendiskusikan pendapat siswa dan mencari kesamaan-kesamaan dari peristiwa yang diamati. Guru memberikan penjelasan berdasarkan pada konsep-konsep yang diperoleh pada fase eksplorasi, kemudian baru siswa diperkenalkan suatu konsep. Pada fase ini akan terjadi pengkonstruksian konsep baru berupa konsep ilmiah, dan terjadi proses asimilasi atau akomodasi yang merupakan pembentukan konsep baru; dan (3) fase aplikasi konsep, pada fase ini guru meminta siswa menguji kesimpulannya dengan mengaplikasikan pada kehidupan sehari-hari (Wena, 2012). Fase ini bertujuan untuk menguatkan kembali gagasan siswa agar sesuai dengan konsep ilmiah dan menyesuaikan prakonsep menjadi konsep ilmiah.

Berdasarkan uraian di atas, masalah utama pada penelitian ini adalah bagaimanakah peningkatan hasil belajar dan literasi sains-teknologi siswa dalam pembelajaran fisika melalui penerapan pendekatan STML dengan strategi siklus belajar empiris-induktif. Tujuan penelitian ini adalah untuk meningkatkan hasil belajar dan literasi sains-teknologi siswa melalui penerapan pendekatan STML dengan strategi siklus belajar empiris-induktif dalam pembelajaran fisika khususnya materi rangkaian listrik dan Hukum Ohm. 


\section{METODE}

\section{Prosedur Penelitian}

Penelitian ini merupakan Penelitian Tindakan Kelas (PTK) yang tujuan utamanya adalah meningkatkan hasil belajar dan literasi sains dan teknologi siswa khususnya dalam pembelajaran rangkaian listrik dan hukum Ohm. Subyek penelitian ini adalah siswa kelas $X$ tahun pelajaran 2020/2021 dengan jumlah siswa 45 orang. Penelitian ini dilaksanakan dalam dua siklus dengan masing-masing siklus terdiri dari empat tahap kegiatan, yaitu tahap perencanaan, tindakan, observasi dan evaluasi, dan refleksi. Tahap perencanaan meliputi; pembuatan rencana pembelajaran, menyiapkan alat-alat percobaan, membuat LKS untuk tiap-tiap pertemuan, membuat angket respon belajar, dan membuat tes hasil belajar pada materi rangkaian listrik dan hukum Ohm, dan tes literasi sains dan teknologi. Tahap pelaksanaan tindakan, yaitu; pelaksanaan pembelajaran sesuai dengan perangkat yang telah disusun (RPP) yang meliputi fase eksplorasi, fase pengenalan konsep, dan fase aplikasi konsep. Para siswa bekerja dalam kelompok dan berpedoman pada LKS. Tahap observasi dan evaluasi, meliputi; kegiatan mengobservasi aktivitas belajar siswa selama pembelajaran dengan bantuan teman sejawat, dan memberikan tes evaluasi pada pertemuan terakhir tiap-tiap siklus. Tahap refleksi, peninjauan kembali pembelajaran yang telah dilaksanakan dengan melihat hasil observasi dan evaluasi tiap siklus.

\section{Instrument Penelitian dan Analisis Data}

Tes hasil belajar yang digunakan dalam penelitian ini adalah tes hasil belajar pada akhir siklus, dalam bentuk soal obyektif dengan jumlah soal sebanyak 15 item soal. Tes literasi sains dan teknologi yang digunakan berupa tes literasi sains dan teknologi dalam bentuk soal uraian dengan jumlah soal sebanyak 10 item dan diberikan pada akhir siklus. Respon siswa terhadap penerapan STML dengan strategi siklus belajar empiris-induktif dikumpulkan dengan angket yang terdiri dari 15 item pernyataan. Penilaian respon siswa menggunakan skala Likert 5 dengan pilihan sangat setuju (SS), setuju (S), ragu-ragu (RR), tidak setuju (TS), dan sangat tidak setuju (STS). Masing-masing pernyataan diberi skor, untuk pernyataan positif adalah $S S=5, S=4, R R=3$, $T S=2$, dan $S T S=1$, sedangkan untuk pernyataan negatif adalah $S S=1, S=2, R R=3, T S=4$, dan $S T S=5$.

Hasil belajar siswa diukur dengan menggunakan tes materi rangkaian listrik dan hukum Ohm. Data hasil belajar siswa dianalisis secara deskriptif kuantitatif. Kualifikasi hasil belajar didasarkan pada pedoman konversi (Nurkancana \& Sunartana, 1992) seperti dalam Tabel 1.

Tabel 1. Pedoman Konversi Hasil Belajar

\begin{tabular}{ccc}
\hline No. & Kriteria & Kualifikasi \\
\hline 1 & $85-100$ & Sangat baik \\
2 & $70-84$ & Baik \\
3 & $55-69$ & Cukup \\
4 & $40-54$ & Kurang \\
5 & $0-39$ & Sangat kurang \\
\hline
\end{tabular}

Data hasil belajar siswa digunakan untuk menentukan persentase ketuntasan secara klasikal (\%KK) dengan kriteria keberhasilan apabila ketuntasan klasikal mencapai $\geq 85 \%$, maka penguasaan konsep dianggap tuntas (Arikunto, 1999).

Data literasi sains dan teknologi siswa terhadap penerapan pendekatan STML dengan strategi siklus belajar empiris-induktif dalam pembelajaran rangkaian listrik dianalisis secara deskriptif kualitatif yang didasarkan pada rata-rata ideal (Mi) dan standar deviasi ideal (Sdi). Pedoman konversi literasi sains dan teknologi siswa dapat dilihat dalam Tabel 2.

Tabel 2. Pedoman Konversi Kualifikasi Kriteria Literasi Sains dan Teknologi

\begin{tabular}{ccc}
\hline No. & Kriteria & Kualifikasi \\
\hline 1 & $X \geq 37,45$ & Sangat baik \\
2 & $29,15 \leq X<37,45$ & Baik \\
3 & $20,85 \leq X<29,15$ & Cukup baik \\
\hline
\end{tabular}




\begin{tabular}{ccc}
\hline No. & Kriteria & Kualifikasi \\
\hline 4 & $12,55 \leq \mathrm{X}<20,85$ & Kurang baik \\
5 & $\mathrm{X}<12,55$ & Sangat kurang baik \\
\hline
\end{tabular}

Data tentang respon siswa terhadap penerapan pendekatan STML dengan strategi siklus belajar empiris-induktif dijaring dengan angket respon siswa yang terdiri dari 15 item pernyataan. Tiap item memiliki skor maksimum 5 dan skor minimum 1. Data respon siswa dikonversi menggunakan Tabel 3 berikut.

Tabel 3. Pedoman Konversi Kualifikasi Kriteria Literasi Sains dan Teknologi

\begin{tabular}{ccc}
\hline No. & Kriteria & Kualifikasi \\
\hline 1 & $X \geq 60$ & Sangat baik \\
2 & $50 \leq X<60$ & Baik \\
3 & $40 \leq X<50$ & Cukup baik \\
4 & $30 \leq X<40$ & Kurang baik \\
5 & $X<30$ & Sangat kurang baik \\
\hline
\end{tabular}

\section{HASIL DAN PEMBAHASAN}

Penelitian dilaksanakan dalam dua siklus, dan masing-masing siklus terdiri dari 4 (empat) pertemuan, hasil penelitian pada setiap siklus dapat dideskripsikan sebagai berikut.

\section{Hasil Penelitian Siklus I}

Hasil penelitian menunjukkan bahwa hasil belajar siswa pada siklus I menunjukkan rata-rata nilai sebesar 65,4 dengan ketuntasan klasikal 44,44\%. Hasil ini menunjukkan bahwa ketuntasan individual siswa belum memenuhi kriteria ketuntasan yang telah ditetapkan sesuai KKM mata pelajaran fisika sebesar 70. Persentase ketuntasan klasikal yang dicapai juga belum memenuhi kriteria ketuntasan karena siswa dikatakan tuntas jika ketuntasan klasikal mencapai $\geq 85 \%$. Untuk lebih jelasnya distribusi hasil belajar siswa pada siklus I dapat dilihat pada Tabel 4 di bawah ini.

Tabel 4. Distribusi Hasil Belajar Siswa Siklus I

\begin{tabular}{ccccc}
\hline No. & Nilai & Jumlah Siswa & Persentase (\%) & Kualifikasi \\
\hline 1. & $85-100$ & 0 & 0 & Sangat baik \\
2. & $70-84$ & 20 & 44,44 & Baik \\
3. & $55-69$ & 20 & 44,44 & Cukup baik \\
4. & $40-54$ & 5 & 11,11 & Kurang baik \\
5. & $0-39$ & 0 & 0 & Sangat kurang baik \\
\hline
\end{tabular}

Distribusi hasil belajar siswa pada Tabel 4 di atas menunjukkan bahwa hanya 44,4\% yang kualifikasi hasil belajarnya tergolong baik dan sisanya tergolong dalam kualifikasi cukup baik dan kurang baik.

Berdasarkan hasil analisis data literasi sains dan teknologi siswa terhadap penerapan pendekatan STML dengan siklus belajar empiris-induktif diperoleh skor rata-rata 35,82 dengan kualifikasi baik. Untuk lebih jelasnya distribusi literasi sains dan teknologi siswa siklus I seperti dalam Tabel 5 di bawah ini.

Tabel 5. Distribusi Literasi Sains dan Teknologi Siswa Siklus I

\begin{tabular}{ccccc}
\hline No & Skor & Jumlah Siswa & Persentase (\%) & Kualifikasi \\
\hline 1. & $X \geq 37,45$ & 18 & 40 & Sangat baik \\
2. & $29,15 \leq X<37,45$ & 21 & 46,67 & Baik \\
3. & $20,85 \leq X<29,15$ & 6 & 13,3 & Cukup baik \\
4. & $12,55 \leq X<20,85$ & 0 & 0 & Kurang baik \\
5. & $X<12,55$ & 0 & 0 & Sangat kurang baik \\
\hline
\end{tabular}

Data tersebut menunjukkan sebagian besar Literasi sains dan teknologi siswa tergolong dalam kualifikasi baik. 


\section{Hasil Penelitian Siklus II}

Berdasarkan analisis data siklus II diperoleh rata-rata hasil belajar siswa sebesar 74,16 dengan ketuntasan klasikal $87,78 \%$. Distribusi hasil belajar siswa pada siklus II dapat dilihat dalam Tabel 6 berikut ini.

Tabel 6. Distribusi Hasil Belajar Siswa Siklus II

\begin{tabular}{ccccc}
\hline No. & Nilai & Jumlah Siswa & Persentase $(\%)$ & Kualifikasi \\
\hline 1. & $85-100$ & 8 & 17,78 & Sangat baik \\
2. & $70-84$ & 27 & 60,00 & Baik \\
3. & $55-69$ & 10 & 22,22 & Cukup baik \\
4. & $40-54$ & 0 & 0 & Kurang baik \\
5. & $0-39$ & 0 & 0 & Sangat kurang baik \\
\hline
\end{tabular}

Data pada Tabel 6 di atas enunjukkan bahwa hasil belajar siswa berada pada kualifikasi cukup baik ke atas. Bila dibandingkan dengan siklus sebelumnya, hasil belajar pada kedua siklus dapat dilihat dalam Tabel 7 di bawah ini.

Tabel 7. Perbandingan Hasil Belajar Tiap Siklus

\begin{tabular}{crcc}
\hline \multirow{2}{*}{ No. } & \multicolumn{1}{c}{ Indikator } & \multicolumn{2}{c}{ Siklus } \\
\cline { 3 - 4 } & & I & II \\
\hline 1. & Jumlah siswa & 45 & 45 \\
2. & Rata-rata nilai & 65,4 & 74,16 \\
3. & Jumlah siswa yang tuntas & 20 & 35 \\
4. & Jumlah siswa yang belum tuntas & 26 & 10 \\
5. & Ketuntasan klasikal & $44,44 \%$ & $87,78 \%$ \\
\hline \multicolumn{2}{r}{ Kualifikasi } & Belum tuntas & Tuntas \\
\hline
\end{tabular}

Berdasarkan hasil analisis data literasi sains dan teknologi siswa terhadap penerapan pendekatan STML dengan strategi siklus belajar empiris-induktif diperoleh skor rata-rata 38,73 dengan kualifikasi sangat baik.

Tabel 8. Distribusi Literasi Sains dan Teknologi Siswa Siklus II

\begin{tabular}{ccccc}
\hline No & Skor & Jumlah Siswa & Persentase (\%) & Kualifikasi \\
\hline 1. & $X \geq 37,45$ & 25 & 55,56 & Sangat baik \\
2. & $29,15 \leq X<37,45$ & 20 & 44,4 & Baik \\
3. & $20,85 \leq X<29,15$ & 0 & 0 & Cukup baik \\
4. & $12,55 \leq X<20,85$ & 0 & 0 & Kurang baik \\
5. & $X<12,55$ & 0 & 0 & Sangat kurang baik \\
\hline
\end{tabular}

Distribusi literasi sains dan teknologi siswa terhadap penerapan pendekatan STML dengan strategi siklus belajar empiris-induktif di atas menunjukkan sebagian besar siswa tergolong dalam kualifikasi baik ke atas.

Berdasarkan hasil analisis data skor respon siswa terhadap penerapan pendekatan STML dengan strategi siklus belajar empiris-induktif diperoleh skor rata-rata 60,98 dengan kualifikasi positif, selengkapnya distribusi respon belajar siswa dapat dilihat dalam tabel 9 di bawah ini.

Tabel 9. Distribusi Respon Siswa

\begin{tabular}{ccccc}
\hline No. & Skor & Jumlah siswa & Persentase (\%) & Kualifikasi \\
\hline 1 & $X \geq 60$ & 31 & 68,89 & Sangat positif \\
2 & $50 \leq X<60$ & 12 & 26,67 & Positif \\
3 & $40 \leq X<50$ & 2 & 4,44 & Cukup positif \\
4 & $30 \leq X<40$ & 0 & 0 & Kurang positif \\
5 & $X<30$ & 0 & 0 & Sangat kurang positif \\
\hline
\end{tabular}

Distribusi respon siswa terhadap penerapan pendekatan STML dengan strategi siklus belajar empiris-induktif di atas menunjukkan 31 orang $(68,89 \%)$ sangat positif, 12 orang 
$(26,67 \%)$ positif, dan jumlah siswa yang responnya cukup positif ke bawah adalah 2 orang $(4,44 \%)$. Secara umum respon kelas rata-rata 60,98 dengan kualifikasi positif.

Berdasarkan hasil analisis data hasil belajar siswa mengalami peningkatan persentase ketuntasan secara klasikal dari $44,44 \%$ pada siklus I menjadi $87,78 \%$ pada siklus II. Peningkatan hasil belajar siswa ini disebabkan karena; (1) siswa mulai terlatih dengan penerapan pembelajaran yang diberikan yaitu menggunakan pendekatan STML dengan strategi siklus belajar empiris induktif, (2) siswa sudah terampil dalam melakukan percobaan dan membuat laporan percobaan, (3) siswa terlatih dalam membuat kesimpulan, (4) siswa terlatih dalam bekerja mandiri dengan kelompok masing-masing karena siswa sudah memiliki pemahaman dan percaya diri. menurut Widiani et al (2017) pendekatan STML pada fase 1 (eksplorasi) siswa diminta untuk mengemukakan isu-isu sosial yang pernah dialami dalam kehidupan sehari-hari, kemudian siswa belajar melalui aksi-reaksi sendiri (melalui percobaan/eksperimen) dan mengerjakan kegiatan-kegiatan yang tertera dalam LKS. Fase 3 (aplikasi konsep), guru meminta siswa menguji kesimpulannya dengan mengaplikasikan pada kehidupan sehari-hari. Fase ini bertujuan untuk menguatkan kembali gagasan siswa agar sesuai dengan konsep ilmiah dan menyesuaikan prakonsep menjadi konsep ilmiah. Menurut Rideng (2000), siswa diberikan kesempatan untuk meramal pengetahuan yang telah diperoleh dari pendidikan, sehingga memecahkan masalah-masalah baru baik yang terprediksi maupun yang tidak terprediksi.

Literasi sains dan teknologi siswa terhadap penerapan pendekatan STML dengan strategi siklus belajar empiris-induktif telah mengalami peningkatan dari skor rata-rata 35,82 dengan kualifikasi baik pada siklus I meningkat menjadi rata-rata 38,73 dengan kualifikasi sangat baik. Peningkatan rata-rata literasi sains dan teknologi siswa ini terlihat dari kemampuan siswa membuat isu-isu sosial yang berkaitan dengan teknologi, masyarakat dan lingkungan yang mereka temui dalam kehidupan sehari-hari yang berkaitan dengan materi pembelajaran. dengan adanya peningkatan skor rata-rata literasi sains dan teknologi siswa, maka dapat dikatakan bahwa penerapan pendekatan STML dengan strategi siklus belajar empiris-induktif dapat meningkatkan literasi sains dan teknologi. Pengajaran sains di sekolah dengan pendekatan STML, mendorong siswa untuk menerapkan ilmu yang dipelajari untuk kehidupan kesehariannya dan juga dalam memecahkan masalah-masalah dalam kehidupan bermasyarakat. Pendekatan STML ini cocok untuk diterapkan khususnya pada pembelajaran fisika karena dengan pendekatan ini siswa dapat memecahkan masalah-masalah yang berhubungan dengan kemajuan sains dan teknologi serta kebutuhan masyarakat dan lingkungan (Sukaisih, 2004). Fase 2 (pengenalan konsep), guru sebagai fasilitator mengadakan diskusi untuk mencari kesamaan-kesamaan dari peristiwa yang diamati siswa. Guru memberi penjelasan berdasarkan pada konsep-konsep yang diperoleh pada fase eksplorasi, kemudian baru siswa diperkenalkan suatu konsep sehingga memberikan kesempatan siswa dalam pengkonstruksian konsep baru berupa konsep ilmiah, dan terjadi proses asimilasi atau akomodasi yang merupakan pembentukan konsep baru (Widiani et al., 2017).

Berdasarkan hasil analisis data respon siswa terhadap penerapan pendekatan STML dengan strategi siklus belajar empiris-induktif menunjukkan rata-rata 59,69 dengan kualifikasi positif. Hasil analisis yang diperoleh melalui penyebaran angket respon, tampak bahwa siswa merasa senang terhadap penerapan pendekatan STML dengan strategi siklus belajar empiris-induktif, seperti: (1) siswa lebih percaya diri dalam melakukan percobaan, menjawab pertanyaan guru, membuat kesimpulan, dan mempresentasikan hasil laporan di depan kelas, (2) siswa merasa senang dengan penjelasan dan penekanan materi yang diberikan oleh guru, dan (3) siswa merasa lebih mudah memahami pelajaran arena selalu dikaitkan dengan kehidupan sehari-hari. Selain itu juga ditemukan hal-hal yang kurang disenangi oleh siswa yaitu (1) siswa kurang senang dalam bekerja kelompok karena ada anggota kelompok yang hanya bercanda, (2) banyaknya tugas-tugas mandiri yang harus mereka kerjakan di rumah sebagai tambahan latihan soal yang membuat siswa merasa terbebani. Dengan adanya skor rata-rata 59,69 dengan kualifikasi positif menunjukkan bahwa penerapan pendekatan STML dengan strategi siklus belajar empiris-induktif dapat meningkatkan respon belajar siswa. 


\section{KESIMPULAN}

Berdasarkan hasil penelitian ini maka dapat disimpulkan bahwa (1) penerapan pendekatan STML dengan strategi siklus belajar empiris-induktif dalam pembelajaran rangkaian listrik dan hukum Ohm dan hambatan dapat meningkatkan hasil belajar siswa yang terlihat dari nilai hasil belajar siswa pada siklus I dengan rata-rata 65,4 dan ketuntasan klasikal 44,44\% meningkat menjadi rata-rata 74,16 dan ketuntasan klasikal $87,78 \%$ pada siklus II; (2) penerapan pendekatan STML dengan strategi siklus belajar empiris-induktif dalam pembelajaran rangkaian listrik dan hukum Ohm dan hambatan dapat meningkatkan literasi sains dan teknologi siswa yang terlihat dari nilai literasi sains dan teknologi pada siklus I tergolong dalam kualifikasi baik (rata-rata 35,82) meningkat menjadi kualifikasi sangat baik (rata-rata 38,73) pada siklus II; dan (3) respon belajar siswa terhadap penerapan pendekatan STML dengan strategi siklus belajar empiris-induktif dalam pembelajaran rangkaian listrik dan hukum Ohm dan hambatan baik pada siklus I dan II adalah tergolong kualifikasi positif (rata-rata 59,69).

\section{REKOMENDASI}

Berdasarkan hasil refleksi secara umum terhadap Penerapan pendekatan STML dengan strategi siklus belajar empiris-induktif dalam pembelajaran rangkaian listrik dan hukum Ohm dan hambatan, maka dapat dikemukakan saran sebagai berikut (1) ketersediaan sumber belajar utama dan tambahan sangat penting menjadi perhatian guru dalam membelajarkan siswa dengan pendekatan STML dengan strategi siklus belajar empiris-induktif dalam menumbuhkembangkan literasi sains teknologi siswa; dan (2) siswa mengalami kesulitan dalam mengemukakan isu-isu sosial (fase satu eksplorasi) yang terkait dengan materi yang dibelajarkan sehingga penyajian ide atau isu sosial yang bersifat umum perlu disajikan di awal pembelajaran.

\section{UCAPAN TERIMAKASIH}

Ucapan terima kasih terutama ditujukan kepada pemberi dana pengabdian atau donatur. Ucapan terima kasih dapat juga disampaikan kepada pihak-pihak yang membantu pelaksanaan pengabdian.

\section{DAFTAR PUSTAKA}

Abdullah, Z. (2019). Pengembangan Perangkat Pembelajaran Berbasis Pendekatan STML untuk Meningkatkan Kemampuan Literasi Sains Peserta Didik. Indonesian Journal of Natural Science Education (IJNSE), 2(1), 125-133. https://doi.org/10.31002/nse.v2i1.432

Ardianto, D., \& Rubini, B. (2016). Comparison of Students' Scientific Literacy in Integrated Science Learning Through Model of Guided Discovery and Problem Based Learning. Jurnal Pendidikan IPA Indonesia, 5(1), 31-37. https://doi.org/10.15294/jpii.v5i1.5786

Arikunto, S. (1999). Dasar-dasar evaluasi pendidikan. Bumi Aksara.

Chusni, M. M., Zakwandi, R., Hasanah, A., Malik, A., Ghazali, A. M., \& Ubaidillah, M. (2018). Scientific Literacy: How is it Evolved to Pre-Service Physics Teacher? Jurnal IImiah Pendidikan Fisika Al-Biruni, 7(2), 219-226. https://doi.org/10.24042/jipfalbiruni.v7i2.2781

Fathurrohman, M. A., \& Astuti, R. K. (2017). Pengembangan Modul Fisika Dasar I Berbasis Literasi Sains. PSEJ (Pancasakti Science Education Journal), 2(2), 163-171.

Kemendikbud. (2017). Panduan Gerakan Literasi Nasional. Kemendikbud.

Khoiriah, M., \& Kholiq, A. (2019). Validitas Perangkat Pembelajaran Fisika Berbantuan EBook Literasi Sains Pada Materi Fluida Dinamis. Inovasi Pendidikan Fisika, 9(1), 779-783.

Kurniawati, L., Aminah, N. S., \& Marzuki, A. (2019). Assessing scientific literacy on optics among high school students in Kudus. Journal of Physics: Conference Series, 1170, 012038. https://doi.org/10.1088/1742-6596/1170/1/012038

Laugksch, R. C. (2000). Scientific literacy: A conceptual overview. Science Education, 84(1), $71-94$.

SCE6>3.0.CO;2-C 
Linder, A., Airey, J., Mayaba, N., \& Webb, P. (2014). Fostering Disciplinary Literacy? South African Physics Lecturers' Educational Responses to their Students' Lack of Representational Competence. African Journal of Research in Mathematics, Science and Technology Education, 18(3), 242-252. https://doi.org/10.1080/10288457.2014.953294

Ni'mah, F. (2019). Research trends of scientific literacy in Indonesia: Where are we? Jurnal Inovasi Pendidikan IPA, 5(1), 23-30. https://doi.org/10.21831/jipi.v5i1.20862

Nurhasanah, N., Jumadi, J., Herliandry, L. D., Zahra, M., \& Suban, M. E. (2020). Perkembangan Penelitian Literasi Sains dalam Pembelajaran Fisika di Indonesia. EDUSAINS, 12(1), 38-46. https://doi.org/10.15408/es.v12i1.14148

Nurkancana, \& Sunartana. (1992). Evaluasi Hasil Belajar. Usaha Nasional.

OCED. (2016). Country Note - Results from PISA 2015 [Report]. https://www.oecd.org/pisa/PISA-2015-Indonesia.pdf

Pahrudin, A., Irwandani, I., Triyana, E., Oktarisa, Y., \& Anwar, C. (2019). The Analysis of Pre-Service Physics Teachers in Scientific Literacy: Focus on the Competence and Knowledge Aspects. Jurnal Pendidikan IPA Indonesia, 8(1), 52-62. https://doi.org/10.15294/jpii.v8i1.15728

Pamungkas, Z. S., Aminah, N. S., \& Nurosyid, F. (2018). Students Critical Thinking Skill in Solving Scientific Literacy using a Metacognitive Test Based on Scientific Literacy. Jurnal Ilmiah Pendidikan Fisika Al-Biruni, 7(2), 161-169. https://doi.org/10.24042/jipfalbiruni.v7i2.2909

Parno, Yuliati, L., \& Munfaridah, N. (2018). The profile of high school students' scientific literacy on fluid dynamics. Journal of Physics: Conference Series, 1013, 012027. https://doi.org/10.1088/1742-6596/1013/1/012027

Pratiwi, S. N., Cari, C., \& Aminah, N. S. (2019). Pembelajaran IPA Abad 21 dengan Literasi Sains Siswa. Jurnal Materi dan Pembelajaran Fisika, 9(1), 34-42. https://doi.org/10.20961/jmpf.v9i1.31612

Rideng, I. M. (2000). Pengaruh Model Pembelajaran IPA dengan Pendekatan SainsTeknologi-Masyarakat terhadap Hasil Belajar Siswa SLTP. STKIP N Singaraja.

Sukaisih, R. (2004). Penerapan Pendekatan Sains-Teknologi-Masyarakat dan Lingkungan (STML) dengan Strategi Siklus Belajar Empiris-Induktif sebagai Upaya Meningkatkan Hasil Belajar dan Literasi Sains-Teknologi Siswa Kelas IIIB2 Semester 1 SMPN 6 Singaraja Tahun Pelajaran 2004/2005. IKIP Negeri Singaraja.

Sukaisih, R. (2013). Penerapan Pendekatan Sains-Teknologi-Masyarakat dan Lingkungan (STML) sebagai upaya Meningkatkan Aktivitas dan Hasil Belajar Siswa pada Pembelajaran Rangkaian Listrik dan Hukum Ohm. Lensa: Jurnal Kependidikan Fisika, 1(2), 139. https://doi.org/10.33394/j-lkf.v1i2.1904

Sukaisih, R., \& Muhali, M. (2014). Meningkatkan Kesadaran Metakognitif dan Hasil Belajar Siswa Melalui Penerapan Pembelajaran Problem Solving. Prisma Sains: Jurnal Pengkajian IImu Dan Pembelajaran Matematika Dan IPA IKIP Mataram, 2(1), 71. https://doi.org/10.33394/j-ps.v2i1.803

Wena, M. (2012). Strategi Pembelajaran Inovatif Kontemporer. Bumi Aksara.

Widiani, N. L. R., Suadnyana, I. N., \& Manuaba, I. B. S. (2017). Pengaruh Model Pembelajaran SETS Berbantuan Media Audio Visual terhadap Kompetensi Pengetahuan IPA Siswa Kelas V. MIMBAR PGSD Undiksha, 5(2), Article 2. https://doi.org/10.23887/jjpgsd.v5i2.10755 